\title{
IMPLEMENTATION OF THE MOTIVATION FUNCTION IN LIBRARIES OF SELECTED MILITARY UNIVERSITIES IN POLAND IN THE LIGHT OF OWN RESEARCH
}

\begin{abstract}
A b s t r a c t: The article presents a fragment of research results on the implementation of the management function in selected libraries of military universities in Poland regarding the function of motivation. In an organization such as the academic library of a military university, motivating is the third most important management function after planning and organizing. Analysis of information infrastructure factors allowed the assessment of the implementation of individual management functions in the analyzed military libraries, motivating function - very important from the point of view of managing information resources. The purpose of the paper is to evaluate the implementation of the motivating function. The assessment of the implementation of the motivating function results in significant implications that may contribute to the optimization of management of the entire information infrastructure of the modern military university library.
\end{abstract}

K e y w o r d s: management, motivating function, information infrastructure, military university library

J E L C o d e: C3, C8, Y1

\section{INTRODUCTION}

The aim of the paper is to evaluate the implementation of the motivating function in contemporary libraries of military universities. The implications resulting from the evaluation of this function may contribute to the optimization of information infrastructure management in modern libraries of military universities. Information infrastructure management is essential for the functioning of modern information centres, such as university libraries. One may be tempted to say that information resources have become the most important,

* Contact information: Anita Kuźnik, Akademia Wojsk Lądowych imienia generała Tadeusza Kościuszki, Wydział Zarządzania, Zakład Ekonomii, ul. Czajkowskiego 109, 51 - 147 Wrocław, email: Anita.Kuznik@awl.edu.pl 
next to human resources, resources of this type of organization (although most probably all others too). The market of library services is developing dynamically and in order to meet its ever-increasing requirements, they should be developed and modernized. The key here is the efficient management of information infrastructure, without which the functioning of modern scientific libraries would not be possible today. This acquires particular importance in the libraries of military universities, which, functioning in the structure of the armed forces, are a part of the security system - it is there that the key information for this system is collected and organized. In the era of hybrid threats, the range of services they provide is increasingly dynamically expanding and evolving. Aiming at the most efficient functioning of modern information centres, which are military libraries, it is necessary to optimize their information resources. Management theory comes in handy, which indicates the need to coordinate management functions. In managing information infrastructure, it is crucial to identify factors that affect its functioning and development. In a research project carried out by a team of scientists at the Faculty of Management of the Gen. T. Kościuszko Military University of Land Forces in Wrocław, titled "Information infrastructure management in the library of a military university", of which the author of this article has the honor to be a member, a detailed analysis of the factors of information infrastructure functionality was performed, comparing data from selected scientific libraries of military universities. As a result, the impact of information infrastructure on the functionality of these organizations was determined and the implementation of the management function was examined. The culmination was the indication of directions to optimize the management of information infrastructure in selected libraries of military universities, which culminated in the creation of a model of information infrastructure management in the libraries of selected military universities in Poland. The author of this article presents a detailed research methodology in the paper entitled "Methodology of the research project on management of information infrastructure in the contemporary military university library" [Kuźnik, 2019]. The results of research on the impact of information infrastructure on key indicators of university libraries' activity were published in the paper entitled "The Implications of Information Technology Infrastructure for Key Performance Indicators of University Libraries - results of the preliminary analysis" [Kuźnik, Stanek, Popławski 2019, pp. 77-89], and the results of a preliminary research on the information infrastructure of selected military libraries were published in the paper entitled (in Polish) "Wptyw infrastruktury informacyjnej na funkcjonalność wybranych bibliotek wojskowych" [Kuźnik, 2019]. The scope of the research project includes selected libraries of military universities in Poland i.e. the Library of the Polish Naval Academy (AMW), the Library of the War Studies University (ASzWoj), the Library of the Military University of Technology (WAT) and the Library of the General 
T. Kościuszko Military University of Land Forces (AWL) were analyzed. The time range is modern times - the data are from the last few years. The research was based on the literature on the subject, legal acts, articles from the professional press, electronic sources and source materials of the studied libraries. Functionality indicators that were the subject of statistical analysis were developed by the Project Analysis of the Functioning of Scientific Libraries in Poland (AFB$\mathrm{N})^{1}$. The indicators selected from the AFBN project have an impact on the information infrastructure. The following research methods were used in the study design: the method of in-depth study of the subject literature and source data, the method of index analysis, statistical methods: the method of taxonomy in the grouping type (based on the study of distance from the pattern), as well as the arithmetic average method and the weighted average method. Statistical methods (taxonomy, arithmetic average and weighted average) were quantitative, while the method of in-depth study of subject literature and source data was qualitative. The research techniques used in the work are statistical data processing using a spreadsheet and logical conclusions.

\section{MOTIVATING AS A MANAGEMENT FUNCTION}

The management functions most frequently mentioned in the literature are planning, organizing, motivating and controlling. However, it is widely recognized that the first classification was made by Henri Fayol in his 1909 book "L'exposee des principles generaux d'administration", distinguishing five basic management functions - i.e. planning (closely related to prediction), organizing (i.e. administrative tasks), coordinating (resources and activities), leading (ordering, issuing instructions, bringing the plan to completion) and controlling (plan implementation). With the development of management sciences, the list of these functions has been constantly evolving [Encyclopedia of Management, Everything about management, 2019]. Ricky W. Griffin says management has four basic functions: planning and decision making, organizing, leading and controlling. Griffin claims that planning means setting organizational goals and determining how to best achieve them. Decision making, which he believes is part of the planning process, involves choosing a mode of action from a set of available options. Planning and making decisions help maintain management efficiency, providing guidance for future actions [Griffin 2017, p. 13].

The effectiveness and efficiency of an organization, including a scientific library, as well as satisfying its social needs, depends on the proper coordination of the planning process, organization as well as motivation and control. This article examines the implementation of the motivating function.

\footnotetext{
${ }^{1}$ https://afb.sbp.pl/afbn/materialy/ [dostęp: 21.11.2019]
} 
The third, after planning and organizing, management function is to motivate employees, which can be defined as a process and one of the management functions regulating the behavior of employed people, so that they can contribute to the achievement of the company's goals. Motivating is a mechanism that regulates and triggers a person's behavior. It is a state of internal tension striving to act in a strictly defined direction, having an unconscious character. The motivation of employees is influenced by the internal state of man, which makes him convinced of the rightness of a given action. Motives have an impact on the formation of beliefs in humans and set the direction of activity and maintain or reduce their course. Motivating is a set of forces that make a person behave in a specific way. This is the most important factor in the process of human resource management, because it significantly determines the results at work, and at the same time is elusive. Opportunities, i.e. the ability to perform work, can be provided by training, while the work environment through which the necessary resources to perform the activities can be fixed by making the necessary adjustments. A problem arises when an employee is not sufficiently or properly motivated to work. Employee behavior is a very complex process and there are often difficulties in identifying the problem and its solution. The employee can perform the task with maximum effort, work with such intensity to avoid admonition or reduce his efforts to a minimum. The goal of managers is to increase the frequency of these first attitudes and reduce the occurrence of the last type of behavior. In order for these desirable employee attitudes to apply in their daily work, attention should be paid to the needs of subordinates. It is from them that the motivation process begins. An example would be to convince an employee of too low pay. He then experiences some shortage, shortage, and has a need to receive more income. Then I am looking for ways to satisfy her, e.g. she puts more effort into the job to get a salary or looking for a new job. Later, he chooses one of the solutions, practices it and assesses the degree of satisfaction of the need. In the case of the first option, when the hard work of the employee results in a raise, most often he accepts his new mode of work for longer. However, if his salary does not increase within a reasonable time, he will look for other solutions.

According to Zdzisław Jasiński, motivating is the impact of various forms and resources on employees so that their behavior is in line with the will of the driver, to pursue the tasks set before them. The essence of motivation is to associate employees' subjective aspirations with the process of implementing the organization's tasks. Tadeusz Kotarbiński has a wonderful thought that aptly captures the essence of motivation. "The point is that a man would willingly do what he must do, that what he must do, he must not do it because he must, in doing what he must, find pleasure and thus improve his work many times, showing generosity in devotion to her." Elżbieta Skrzypek states that "motivation is an internal force that allows you to achieve success in every area of life. 
It guarantees great cooperation in the team and the possibility of achieving difficult goals. Motivating is the ability to use energy for human development" (in Polish) [Encyklopedia Zarządzania. Wszystko o zarządzaniu, 2019].

Griffin also talks about motivating that it is a set of forces that make people behave in a certain way (in Polish) [Encyklopedia Zarządzania. Wszystko o zarządzaniu, 2019]. Motivating is an important task for managers, because motivation, along with individual capabilities and talents as well as environmental factors, determines the individual achievements of the employee. We can also find the principles of effective employee motivation in various management studies. The first principle of effective use of gratification procedures is the selection of those reinforcements that have a strong and lasting rewarding ability for subordinates. The second principle of rewarding is to structure the gratification procedures in such a way that the reward obtained is determined by the desired behavior. The third principle of structuring reward conditions is to design and incorporate into the structure of the organization efficient mechanisms to stimulate and release desired behaviors. This means that performance standards should be set at the level of the ability of contractors to work.

According to the fourth principle of structuring the conditions of rewarding, a manager should not reward all employees equally. When rewarding subordinates, the manager should compare their performance with established performance standards and differentiate employee bonuses accordingly. The assumptions of Adams' theory of equality show that managers who tend to reward their subordinates undifferentially at best encourage employees to average work results. On this principle, the behavior of people achieving high results at work is ignored, while the behavior of people achieving mediocre results at work is reinforced by achieved. According to the fifth principle of structuring the conditions of rewarding, the manager should inform subordinates about what kind of behavior in the work environment leads to the desired rewards. An employee who knows the performance standards has an internalized feedback system enabling him to assess his own level of performance (in Polish) [Encyklopedia Zarządzania. Wszystko o zarządzaniu, 2019].

Agnieszka Knap-Stefaniuk, Wioleta J. Karna and Eva Ambrozová point out in their article that the motivation process and its results depend on the assumptions and motivational tools properly selected in the organization, the consequences of using the implemented solutions, as well as making changes in the incentive system if they are necessary in the context of employees' needs and expectations. That is why it is so important in contemporary organizations to constantly expand and update the knowledge of managers in the field of employee motivation. It is the managers' motivational abilities and the ability to react quickly to changes in the field of motivational tools used as well as their willingness to make changes in existing incentive systems, the direction of achieving 
the goals of the teams and the entire enterprise depends to a large extent [Knap-Stefaniuk., Karna J. Wioleta., Ambrozová E, 2018, p. 87].

In turn, according to Zbigniew Ciekanowski, motivation is the process of choice that an employee makes between different behaviors and forms of activity, the purpose of which is to realize what is worthy and desirable. Motivation can be formed by using different values that each employee wants to achieve at work, as well as through the quality of work and the goals that he considers possible to achieve [Ciekanowski Z, 2013, p. 177].

Aleksandra Czarnecka in her publication mentions a comprehensive (integral) model of motivation. The author draws attention to the fact that human motivations and his commitment to work are complex, which confirms the importance of the personnel function, the implementation of which requires special competences. A good supervisor is not only one who gets to know his employees, their needs, values that they follow in their life, or understands them, but is one who has the right knowledge about stimuli through which he can influence the level of organizational behavior of his employees [Czarnecka A., 2011, p. 73]. According to Jerzy Wiśniewski and Ewa Luty, both economic sciences, organization and management as well as psychological sciences are involved in motivating. Motivation is the main factor that triggers the following chain of reactions: its beginning is felt needs, causing specific demands or shaping goals, which in turn lead to an increase in mental tensions (associated with unfulfilled desires) and, as a consequence, to take actions aimed at achieving the set goals [Wiśniewski J., Luty E., 2016, p. 108].

Agata Miszczak and Joanna Walasek have made some classification of motivations. In their article, the authors claim that the effective functioning of the entire incentive system and its improvement caused the need to classify the motivation as: internal motivation, i.e. one that stimulates action and has value in itself, e.g. a passion for something; external, i.e. one that creates an incentive to act and is in some way rewarded or allows you to avoid punishment, e.g. stopping the car at the signal of a policeman. Internal motivation is more beneficial for the organization as a positive attitude to work compared to external motivation. This situation is caused by the fact that the employee derives pleasure from his work, at the same time he is interested in it, namely he is willing to act and improve in his profession. In turn, external motivation enhances action, but it can also weaken the impact of internal motives [Miszczak A., Walasek J., 2015, p.55].

In the military university library, motivating is the most important factor in the process of human resource management (HRM). Managers of individual departments, as well as the director of the library himself should interact through various forms and resources on employees so that their behavior is in line with the will of the library managers. Employee motivation should become a guarantee of good cooperation in the team and the possibility of achieving difficult 
goals. Motivating is an important task for directors / managers of libraries of military universities, because it is motivation that determines the individual achievements of the employee. In a situation when employees are properly motivated, the quality of services increases, and thus increases the library's functionality.

\section{IMPLEMENTATION OF THE MOTIVATION FUNCTION IN SELECTED MILITARY UNIVERSITY LIBRARIES}

In the analyzed libraries one can indicate activities undertaken in the area of information infrastructure that had an impact on the implementation of the motivating function in them. Some of them were implemented correctly, and some of them show shortcomings or errors, and so:

1) In the Library of the Gen. T. Kościuszko Military University of Land Forces (MULF), the correct implementation of the motivating function is evidenced by the highest number of publications of library employees per employee of the basic activity among the analyzed libraries. Therefore, employees are properly motivated by their superiors - not only for professional but also for scientific work. In addition, the number of hours of participation in vocational training per library employee also shows proper motivation. In the MULF Library, this indicator is very high - it indicates that employees are well motivated to participate in trainings that improve their qualifications and skills, which, after all, directly affects both the functionality of the library and the quality of its services.

2) In the Lech Kaczyński Main Library of the Polish Naval Academy of the Heroes of Westerplatte, incorrect implementation of the motivating function is evidenced by the lowest among the analyzed libraries the number of publications of library employees per employee of the basic activity. Employees are probably inadequately encouraged to develop scientifically. Also, the very small number of hours of participation in vocational training per library employee indicates a low motivation of employees to improve their qualifications by taking part in training.

3) Taking into account the analyzed indicators in the Library of the War Studies University, it is difficult to observe the activities undertaken in the implementation of this function.

4) Also in the Jarosław Dąbrowski Main Library of the Military University of Technology, taking into account the analyzed indicators, there are no such activities. 


\section{FUNCTION OF MOTIVATING IN THE MODEL OF INFORMATION INFRASTRUCTURE MANAGEMENT OF THE MILITARY UNIVERSITY LIBRARY}

Commonly "a model" is the closest possible representation of the most important features of the original. The basic purpose of modeling in science is to simplify the complex reality so that it allows it to undergo a research process. Thanks to modeling, one can examine a selected aspect of an issue, omitting others - e.g. information resources in the general resources of a given organizational unit, without examining the issue of total resources in all comparable organizations. In the research project entitled "Information infrastructure management in the library of the military university" implemented at the Faculty of Management of the MULF, the set of isomorphic elements in relation to the given original system was adopted as a model, but simpler and more easily accessible for research. T. Gospodarek distinguishes three types of models: semantic, analogous and mixed interoperability models. The model of the information infrastructure management process in the library of a military university can be included among the models of mixed interoperability in a subtype of data models. Objects treated as models are physical objects, fictitious objects, descriptions, dependencies, logical constructions and all possible combinations thereof. The model constructed by the author is abstract because its physical shape in the form of a diagram illustrating the system of factors determining individual management functions is a fictional creation. One may be tempted to say that the designed model is in the fourth type - an interactive approach to the ideal (next to reacting, inaction and acting for the future), which they write in their work entitled "Designing an ideal. Shaping the future of the organization" Russel L. Ackoff, Jason Magidson and Herbert J. Addison, because the planning takes place here for the place where the author would like the library to be currently [Ackoff, Magidson, Addison, 2007, p.3].

The table below shows the implementation of the motivating function in the information infrastructure management process in the light of own research. In addition to the factors that were subjected to a detailed analysis, the author added other, equally important, which she indicated based on direct observation and interview, as well as her own experience gained during many years of work at the Library of the MULF, where they perform various functions (including managerial functions). 
Table 1. Information infrastructure management process in the library of a military university

\section{PLANNING}

A. Expenditure planning for printed Polish and foreign books as a percentage of expenditure on library collections.

B. Planning the library budget for the appropriate increase in collections (in the form of a book).

C. Planning the library budget so that expenses per user in PLN are adequate.

D. Planning the library budget so that expenses for electronic resources per user in PLN are adequate.

E. Planning appropriate expenses for printed books per student in PLN.

F. Planning the appropriate budget in the library budget for the cost of using the collections.

G. Planning the appropriate number of printed books per student.

H. Planning work on computer-generated printed books in relation to the total number of printed books (in\%).

I. Planning the purchase of printed books taking into account the number of users.

J. Planning the right number of training hours and classes for users in relation to the number of library employees.

K. Planning the right number of places to work in the library in relation to the number of students.

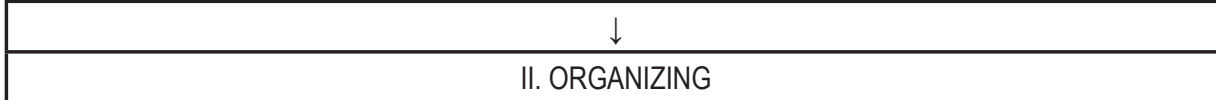

A. Employing the number of library employees adequate to the number of users.

B. Organizing enough work space in the library to match the number of users.

C. Organizing business hours (weekly) during which library services are available.

D. Organization of an appropriate number of training hours and classes for users per library employee.

E. Organizing free access to books including the total number of books in collections.

F. Employing as many employees as possible with a university degree in librarianship in relation to the core business employees.

G. Organizing the shortest possible time for the adoption of a book.

H. Organizing the right amount of work space in the library in relation to the number of students.

I. Creating access to network and / or interactive services. 
III. MOTIVATING

A. Enabling and encouraging library employees to publish their work, including the number of employees in the core business.

B. Enabling participation in vocational training, taking into account the number of library employees.

C. Enabling and encouraging active participation in national and international conferences on the subject of library, as well as in other scientific events.

D. Access to language courses.

\section{CONTROLLING}

A. Control the number of non-electronic library files per user.

B. Control the number of printed books per user.

C. Checking the number of rentals per active borrower.

D. Control of the number of users per library employee.

E. Control of collection growth (in the form of a book and other non-electronic collections).

F. Control the number of downloaded documents from licensed electronic magazines and full-text databases.

G. Control of the cost of using the collection.

H. Control of the number of printed books per student.

I. Control of the computer development process of printed books including the percentage of the total number of printed books.

J. Control of the purchase of printed books in relation to the number and needs of users.

K. Control the number of publications of library employees in relation to the number of employees of the basic activity.

Source: Own elaboration

The figure below shows the place of the motivating function in the information infrastructure management model at the library of a military university. 
Figure 1. Coupling of management functions in libraries of military universities in the light of the results of own research

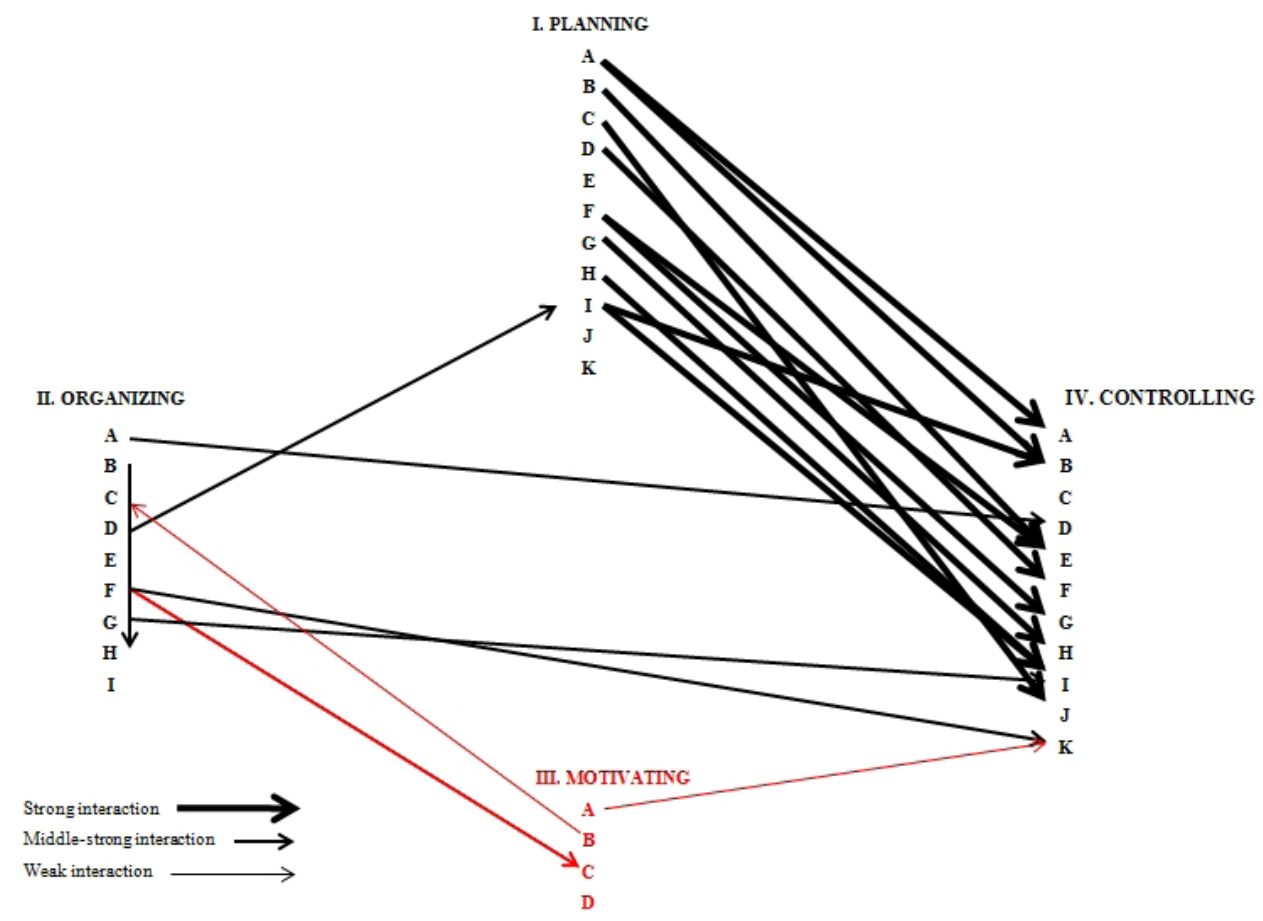

Source: Own elaboration

\section{IMPLICATIONS ARISING FROM THE DEVELOPED MODEL}

As indicated in the model presented in Figure 1, there are significant interactions between planning, organizing, motivating and controlling functions that should be considered when attempting to optimize the entire information infrastructure management process at a military library.

Studies have shown that the planning and controlling functions in the library of military universities are particularly strongly coupled, which implies the following conclusions for actions that may contribute to the optimization of management of its information infrastructure:

1. I A - IV B, IV A: Planning expenditure on printed Polish and foreign books, in particular as a percentage of expenditure on library collections, should be carried out using data from the control of the number of printed books per user and the number of non-electronic library collections per user.

2. IB - IV E: Planning the library budget for the purpose of appropriate collection growth (in the form of a book) should be made using data from 
the collection growth control (in the form of a book and other non-electronic collections).

3. IC - IV J: Planning the library budget including expenses per user in PLN should be made using data from the control of the purchase of printed books in relation to the number and needs of users.

4. ID - IVF: Planning the library budget including expenditure on electronic resources per user in PLN should be made using data from the control of the number of downloaded documents from licensed electronic magazines and full-text databases.

5. I F - IV E, IV G: Planning the appropriate budget in the library's budget for the cost of using the collection should be made using data from the control of the increase in the collection (in the form of books and other non-electronic collections) and the cost of using the collections.

6. I G - IV H: Planning the appropriate number of printed books including the number of students should be made using data from the control of the number of printed books per student.

7. I H - IV I: Planning work on computer-generated printed books in relation to the total number of printed books (in \%) should be carried out using data from the control of the process of computerized printed books including the percentage of the total number of printed books.

8. I I - IV I: Planning the purchase of printed books taking into account the number of users should be made using data from the control of the process of computerized printed books including the percentage of the total number of printed books.

9. I I - IV B: Creating access to network and / or interactive services should be done using data from the control of the number of printed books per user.

In addition, in the studied libraries visible significant coupling with the organizing function show the functions of controlling, planning and motivating, which also implies conclusions for actions that can contribute to the optimization of management of its information infrastructure:

1. IIA - IV D: Hiring the number of library employees adequate to the number of users should be made using data obtained from the control of the number of users per library employee.

2. II D - I J: The organization of an appropriate number of training hours and classes for users per library employee should be preceded by their planning using audit data.

3. II B - II H: Organizing the appropriate number of places to work in the library relative to the number of users should be preceded by planning taking into account the number of students. 
4. IIF - III C, IV K: Employment in the library should be conditioned by having a university degree in librarianship, while employees should be able and encouraged to actively participate in national and international conferences on the subject of library, as well as in other scientific events. Both candidates and employees already employed should be checked regarding the number of publications in relation to the number of employees in the core activity.

5. II G - IV I: Organizing the shortest possible adoption of a book should be preceded by a control of the process of computer-printed printed books, taking into account the percentage of the total number of printed books.

Research has also shown that to some extent, the functions of controlling and organizing in the library of a military university are linked to motivation, which also implies some conclusions for actions that may contribute to optimizing the management of its information infrastructure:

1. III A - IV K: Enabling and encouraging library employees to publish their work, taking into account the number of employees of the basic activity, should be preceded by checking the number of publications of the library employees in relation to the number of employees of the basic activity.

2. III B - II C: Enabling library employees to participate in vocational training in relation to the number of library employees should take into account the organization of their working hours (weekly) in which library services are available.

\section{SUMMARY}

Information infrastructure management in the library of a military university is of key importance for the functioning of this type of organization as modern information centers. The proposed model of the information infrastructure management process in the library of the military university allowed for listing the most important elements in each of the management functions that are essential for the proper functioning of libraries. Interactions between the discussed management functions occur, which the author took into account when trying to optimize the entire information infrastructure management process in the library of a military university. In her research, the author showed that in libraries of military universities the function of planning and control is particularly linked, the visible link shows the function of organizing with the functions of controlling, planning and motivating, as well as to some extent the functions of controlling and organizing are linked with motivating. The theoretical model of managing the information infrastructure of the library of the military university created is a contribution to further research, which will be developed in the future. It can be 
used as part of the decision support system in managing the resources of modern information centers. The above considerations give rise to some recommendations for the authorities of individual libraries of military universities. In the Main Library of the War Studies University, it is recommended to increase the number of places to work in the library for stationary customers by acquiring additional usable space, as these activities would motivate them to increase the frequency of using library services this way. In the Jarosław Dąbrowski Main Library of the Military University of Technology, the management of the library should better take care of training and didactic classes for clients of their services (users), motivating them through these activities to a wider use of them. In the Library of the General Tadeusz Kościuszko Military University of Land Forces, personnel policy is properly conducted both in terms of recruitment and motivating library employees to scientific development. In the Lech Kaczyński Main Library of the Polish Naval Academy, activities related to the organization of the library space intended as a place to work, investment in collections (in the form of books), computer development of printed books as well as the provision of network and / or interactive services should be continued, as these activities motivate all its stakeholders by increasing their activity. On the other hand, motivating employees for professional development leaves much to be desired - they should be encouraged to publish as well as participate in professional training.

\section{LITERATURE}

Ackoff R.L., Magidson J., Addison H.J., (2007). Projektowanie ideału. Kształtowanie przyszłości organizacji, Wharton School Publishing, Wyd. Akademickie i Profesjonalne, WSPiZ im. L. Koźmińskiego, Warszawa

Ciekanowski Z., (2013), Pozapłacowe instrumenty motywowania w organizacji, „Zeszyty Naukowe Uniwersytetu Przyrodniczo-Humanistycznego" Seria: Administracja i Zarządzanie, Nr 99, Siedlce, 2013

Czarnecka A., (2011) Rola przełożonego w kształtowaniu motywacji pracowników, „Zeszyty Naukowe Politechniki Częstochowskiej. Zarządzanie”, nr 3, Politechnika Częstochowska 2011

Encyklopedia Zarządzania. Wszystko o zarządzaniu, (2019), https://mfiles.pl/pl/index.php/Motywowanie_pracownik\%C3\%B3w; [access: 30.03.2019]

Encyklopedia Zarządzania. Wszystko o zarządzaniu, (2019), https://mfiles.pl/pl/index.php/Funkcje_zarz\%C4\%85dzania; [access: 30.03.2019]

Griffin R.W., (2017), Podstawy zarządzania organizacjami, Wydawnictwo Naukowe PWN, Warszawa 2017

Knap-Stefaniuk., Karna J. Wioleta., Ambrozova E.,(2018), Motywowanie pracowników jako ważny elemnet zarządzania zasobami ludzkimi-wyzwania dla współczesnej edukacji, „Kwartalnik Naukowy Uczelni Vistula", 2(56), Warszawa, 2018

Kuźnik A., (2019), Methodology of the research project on management of information infrastructure in the contemporary military university library [in:] S. Stanek, M. Popławski (ed.), "Decisions in Situations of Endangerment. Multidiscipinarity of The Decision Making Process, part II", Wyd. AWL we Wrocławiu, Wrocław 2019 
Kuźnik A., Popławski M., Stanek S., (2017), The Implications of Information Technology Infrastructure for Key Performance Indicators of University Libraries - results of the preliminary analysis, "International Journal of Synergy and Research:, vol. 6, UMCS, Lublin 2017

Kuźnik A., (2019), Influence of information infrastructure on the functionality of selected military university libraries, "AUNC Zarządzanie"

Miszczak A., Walasek J., (2015), Wybrane czynniki motywujące pracowników do pracy w organizacji” Obronność. Zeszyty Naukowe”, Nr 1(13), Akademia Obrony Narodowej, 2015

Wiśniewski J., Luty E., (2016), Proces motywowania w organizacji, „Zeszyty Naukowe Uniwersytetu Przyrodniczo-Humanistycznego" Seria: Administracja i Zarządzanie, Nr 108, Siedlce, 2016 
